\title{
ЭКОЛОГИЯ
}

И ПРИРОДОПОЛЬЗОВАНИЕ

DOI: http://dx.doi.org/10.15688/jvolsu11.2015.1.4

УДК 338: 502.521

ББК 65.281

\section{USE OF THE REGULARITIES OF WITHIN-FIELD VARIABILITY OF ARABLE SOIL FERTILITY IN PRECISION AGROTECHNOLOGIES}

\author{
Afanasyev Rafail Aleksandrovich \\ Doctor of Agricultural Sciences, Professor, \\ All-Russian Scientific and Research Institute of Agrochemistry named after D.N. Pryanishnikov \\ rafail-afanasev@mail.ru \\ Pryanishnikova St., 31A, 127550 Moscow, Russian Federation
}

\begin{abstract}
The paper states the regularities of the within-field variation of soil fertility which are important for variable rate fertilizer application under conditions of precision agrotechnologies including the technologies which limit the agroeconomic efficiency. As it is well known, the usual (traditional) fertilizer practice stipulates their application taking into account average indices of soil fertility: mobile plant food elements (N, P, K etc.) content in the plow layer. At the same time, one part of the plants gets excess of mineral nutrition, and the other part - its deficiency. That results in shortage of agricultural products, their deterioration and also the pollution of the environment and the soil with the excesses of agrochemicals in overfertilized plots. In the last decades traditional technologies give place to high-precision agrotechnologies with differentiated fertilizer application taking into account within-field heterogeneity of soil fertility. There are several constraints for widespread adoption of high-precision agrotechnologies including the underestimation of the character of within-field variability of soil quality. Our investigations reveal eight regularities of the within-field variation of agrochemical indices, which characterize soil fertility in arable soils. These regularities would allow to more seriously estimate the efficiency of variable rate fertilizer application under conditions of precision agrotechnologies.
\end{abstract}

Key words: soil, within-field contours, variability, regularities, precision agriculture. 


\section{Introduction}

The main procedures of precision agriculture include differentiated agrochemical application when taking into account within-field variability of fertility and crop status. The agrochemicals are mineral and organic fertilizers, amendments and other inputs. The usual (traditional) fertilizer practice utilizes average rate of fertilizer usage for an individual field. As a rule both procedures use soil analysis when calculating optimal rate of fertilizer. Users employing the traditional technology calculate the optimal rate by averaging results of soil analysis of the whole field; the alternative technology prescribes averaging the results for every within-field contour. Since now there are not visual contours of within-field boundaries all the processes of differentiated application of agrochemicals use satellite navigation system (GPS - Global Positioning System). There are many ways of admeasurement of these contours which are differentiated one from another by fertility level. These ways are small-grid sampling and the agrochemical analysis of these samples throughout an entire field with later geostatistic data processing; preliminary yield, electroconductivity or landscape scanning; remote (aerospace) sensing of earth surface. Sampling and analyzing are carried out within the bounds of these contours formerly a priori distinguished and created by some way for calculating differentiated fertilizer and amendment rate and their application realized off-line. For differentiated nitrogen additional fertilizing of vegetating crops they use the photometric methods of nitrogenous nutrition diagnostics by biomass green color or determine elasticity of herbage by crop-meter. The diagnostic devices of these technologies are coordinated with fertilizer applicator which works on-line. This is the general scheme of preparation and carrying out of procedures for differentiated application of agrochemicals under conditions of precision agriculture.

Accordance with the usual standpoint of ordinary agrochemists they hope for increasing returns under conditions of differentiated application as compared with application by averaged rate because of different fertility of individual plots. Due to this additional expenditures caused by placing of hard- and dataware of high- precision agrotechnologies might be compensated. However the experience of many agriculturalists shows necessity elaborating new ways of decision the problem. In particularly investigations performed in the USA (United States of America) (state Idaho) [8] over a 30-year period with conventional and variable rate nitrogen fertilizer application (data obtained from a seed potato operation) indicated discouraging result: variable rate nitrogen application was found to be unprofitable for the field when compared uniform nitrogen application since the total costs associated with variable rate fertilizer application outweighed the benefits obtained from maintaining the optimal plant available nitrogen levels. This is not unique information concerning the theme. Besides that there are a certain traditional character of agriculture and a sluggishness of landusers thinking. As a result in the last decade there is the decline of interest in the differentiated application of fertilizers. The decline could be explained by the cyclical nature of the development of new technologies [4].

Our investigations show that for practical use of differentiated application of fertilizers it is important more accurately take into account features of within-field variability of soil fertility and mineral nutrition including the features limiting prospective efficiency.

\section{Experimental part}

The main methods of the investigations were statistical and graph-analytical analysis and the generalizations of the agrochemical characteristics of the plow layer of sod-podzolic clay loam soil. Site: Testing area of the Central Experiment Station of the Pryanishnikov AllRussian Agrochemistry Research Institute (Moscow region). Testing area was a part of cropping rotation field that comprised about 4 ha $(200 \times 200 \mathrm{~m})$. The part included $40010 \times$ 10 -m square plots on which 400 composite soil samples were taken and analyzed. Taking soil samples and their agrochemical analysis were carried out in accordance with the methods used in the agrochemical service and Russian scientific institutes. Humus (organic carbon) content was analyzed by Tiurin's method (oxidation of soil organic matter in $\mathrm{K}_{2} \mathrm{Cr}_{2} \mathrm{O}_{7}+$ $\mathrm{H}_{2} \mathrm{SO}_{4}$ ), mobile potassium and mobile 
phosphorus - by Kirsanov's method ( 0.2 normal $\mathrm{HCl}$-soil extract), easy-mobile potassium and easy-mobile phosphorus -in low saline $\mathrm{CaCl}_{2}$ extract, easy-hydrolysable nitrogen - in 0.5 normal $\mathrm{H}_{2} \mathrm{SO}_{4}, \mathrm{~N}_{-} \mathrm{NO}_{3}$ - in $\mathrm{H}_{2} \mathrm{O}$-extract, $\mathrm{pH}$ in saline suspension ( $\mathrm{KCl} 1$ normal) [3].

\section{Results and discussion}

We revealed eight regularities concerned within-field variability of agrochemical indices. The regularities would be important for technologies of precision agriculture. In the first place it was found that the soil reaction as well as humus and mobile phosphorus and potassium content more or less corresponded to a normal distribution.

In fact, plots with the relatively average values of the easy-hydrolysable nitrogen, mobile phosphorus and potassium content occupied more than half of the area, while the number of plots with bulk and minority of the content were noticeably less (fig. 13). Thus, 350 plots contained $101-250 \mathrm{mg} / \mathrm{kg}$ mobile $\mathrm{P}_{2} \mathrm{O}_{5}$ in their soil, while plots with lower and higher values of these indices occupied minimum square. Similar results characterized territorial distribution of sites with different easy-hydrolysable nitrogen and mobile potassium.

The second feature of soil spatial structure as used here is that the maximum characteristic of agrochemical indices variability (easy-hydrolysable nitrogen, mobile potassium and mobile phosphorus) was found in plots that had relatively smaller and larger values of the content while decreasing the variability in average interval (fig. 4-6). When investigating the plots which had the average values of mobile phosphorus content we found that coefficient of variability of these indices was smaller than $5 \%$, while it exceeded $15-25 \%$ for the plots with marginal indices. Coefficient of correlation between the theoretical calculations and the facts $(R)$ was 0.89 .

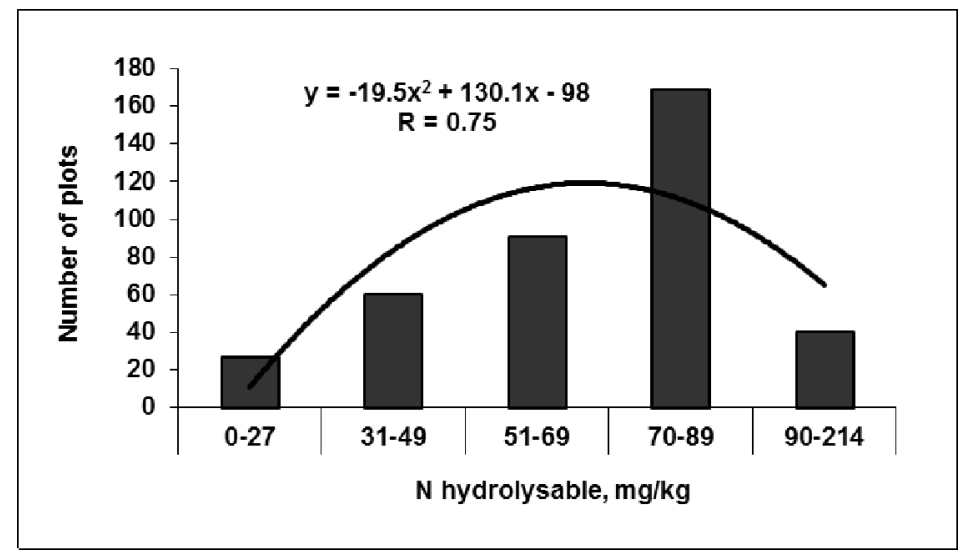

Fig. 1. Curve of the distribution of the number of 400 plots versus $\mathrm{N}$ hydrolysable content in the CES testing area soil

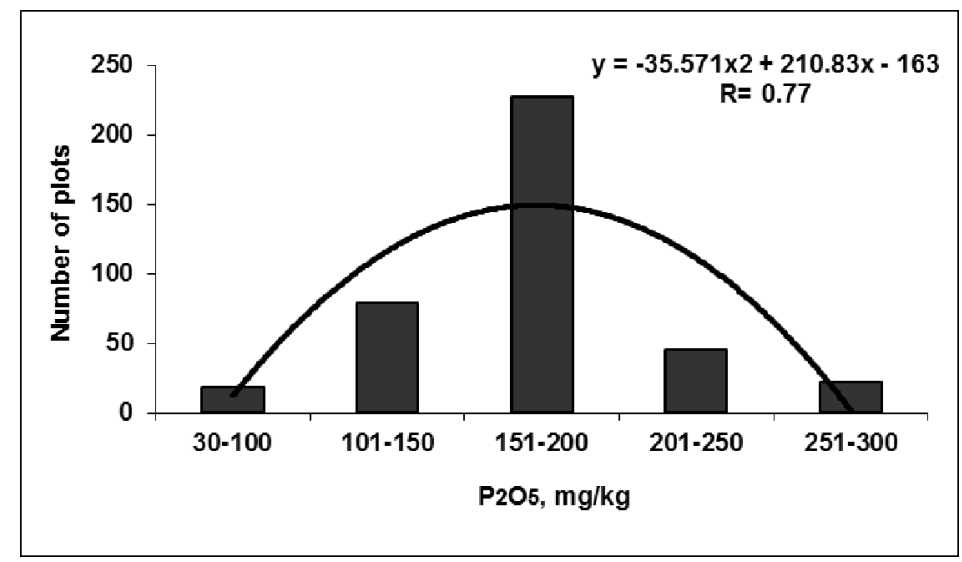

Fig. 2. Curve of the distribution of the number of 400 plots versus mobile phosphorus $\left(\mathrm{P}_{2} \mathrm{O}_{5}\right)$ content in the CES testing area soil 


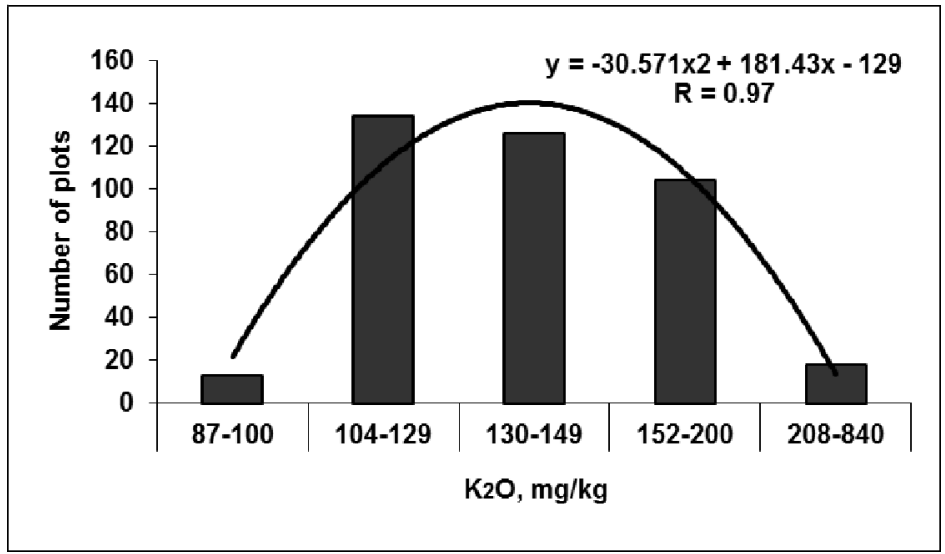

Fig. 3. Curve of the distribution of the number of 400 plots versus mobile potassium $\left(\mathrm{K}_{2} \mathrm{O}\right)$ content in the CES testing area soil

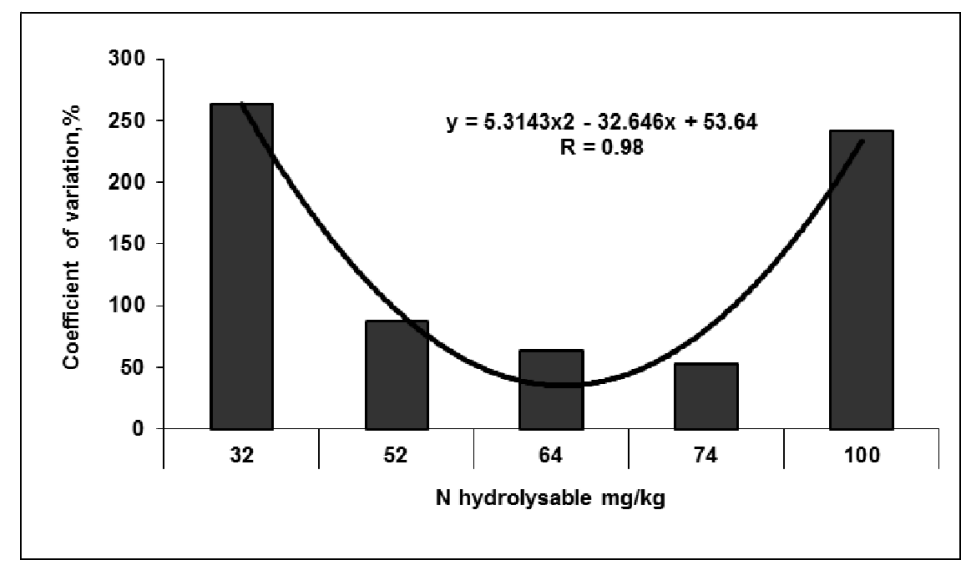

Fig. 4. Variability of $\mathrm{N}$ hydrolysable content in soils of the 400 plots of agricultural test area

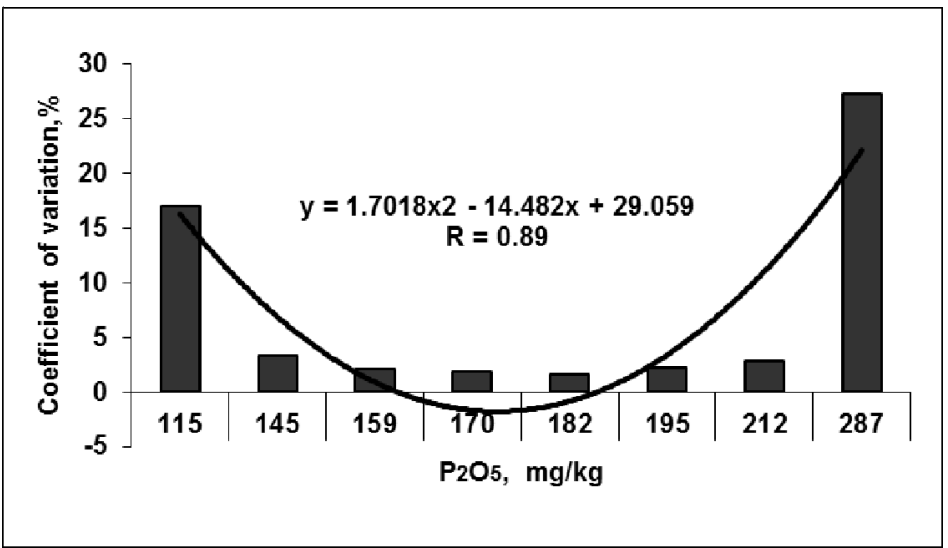

Fig. 5. Variability of mobile phosphorus content in soils of the 400 plots of agricultural test site 


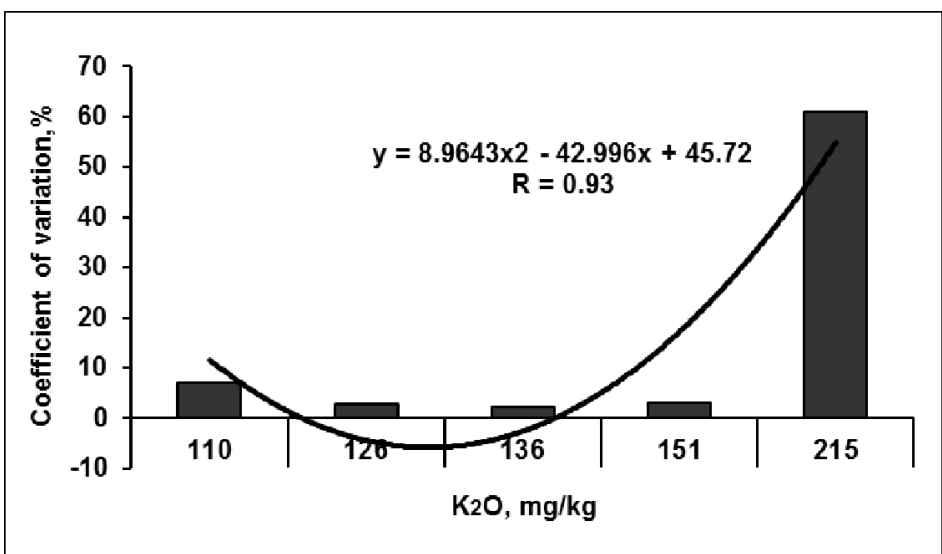

Fig. 6. Variability of mobile potassium content in soils of the 400 plots of agricultural test site

In accordance with the second regularity agroeconomic efficiency of variable rate fertilizer application in specific case will depend on the ratio of plots with marginal values of agrochemical characteristics to plots with their average characteristics: the efficiency increased when the ratio was more. But number of plots with marginal characteristics of the soil, according to the first regularity, was at the edges of the normal distribution curve i. e. their total area was far smaller than the area of the plots with average agrochemical characteristics for a given field. So the efficiency of variable rate agrochemicals applications determinates by these regularities.

The third regularity: intrafield variability of soil fertility can surpass inter-field variability. This was because an increase of the land area which was used for averaging-out of agrochemical indices reduced inter-contour variability and increased within-contour variability and vice versa. The regularity was found in the testing area of the Central Experiment Station of the Pryanishnikov All-Russian Agrochemistry Research Institute (tab. 1).
According to table 1, variability of withingroup humus as well as mobile $\mathrm{P}$ and $\mathrm{K}$ considerably (ten times as large) increased with increasing elementary plot area from 0.1 to 4 ha. It is necessary to take into account this regularity when developing high agrotechnologies finding a compromise between the expediency of distinguishing fertility contours with minimum intracontour variability of soil fertility for increasing fertilizer efficiency, on the one hand, and the minimum number of such field contours for reducing the cost of taking and analyzing soil samples, on the other. The most acceptable is selection by methods of geostatistics in one plot as a rule no more than 5-6 contours with different level of soil fertility. Thus it is necessary use every agrochemical index according to general area of a field. The fourth regularity of spatial heterogeneity of the soil cover consists in the smooth, gradual transition from the maximum values of the agrochemical indices to smaller and vice versa from smaller to maximum (fig. 7).

Line of trend that describes the change of mobile phosphorus content of $200 \mathrm{~m}$ transect of the agricultural test site in limits $170-276 \mathrm{mg} / \mathrm{kg}$

Table 1

Dependence of variability of soil agrochemical indices on the area of the plots being averaged

\begin{tabular}{|c|c|c|c|c|}
\hline \multirow{2}{*}{ Number of plots } & \multirow{2}{*}{ Plot area, ha } & \multicolumn{2}{|c|}{ Coefficients of variation of agrochemical characteristics, $V^{\circ}$} \\
\cline { 3 - 5 } & & humus & $\mathrm{P}_{2} \mathrm{O}_{5}$ & $\mathrm{~K}_{2} \mathrm{O}$ \\
\hline 40 & 0.1 & 0.8 & 2.1 & 2.4 \\
\hline 20 & 0.2 & 1.6 & 3.5 & 4.6 \\
\hline 8 & 0.5 & 3.2 & 7.3 & 10.0 \\
\hline 4 & 1.0 & 5.6 & 12.6 & 17.1 \\
\hline 2 & 2.0 & 10.0 & 20.8 & 27.6 \\
\hline 1 & 4.0 & 18.6 & 30.7 & 41.2 \\
\hline
\end{tabular}




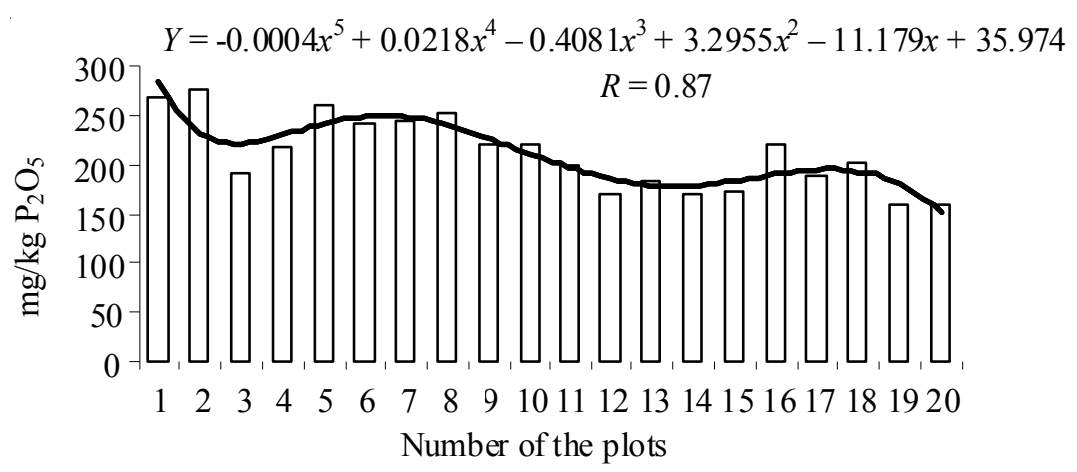

Fig. 7. Mobile phosphorus content in soil of $200 \mathrm{~m}$ transect of the agricultural test site

$\mathrm{P}_{2} \mathrm{O}_{5}$ approximates the facts with coefficient of correlation $R=0.88$. Consideration of this characteristic of the soil structure is very important from a practical viewpoint since when designing and creating machines for variable rate agrochemicals application it allows providing for a comparatively smooth change of their rates during travel over the field. This facilitates both designing and operating processes of fertilizer and amendment application under production conditions.

The fifth regularity of within-field variability of agrochemical indices in this context is the dependence of the level of soil fertility level on the meso- and microtopography of fields which to a considerable extent causes all the above-mentioned regularities. Soils of one topographic location influence surrounding soils by leaching, nutrient transfer and deposition of chemical components. Under conditions of the testing area $\mathrm{N}-\mathrm{NO}_{3}$ content in soil of elevations prevails over $\mathrm{N}-\mathrm{NH}_{4}$ content, whereas in depressions ammonium-nitrogen content exceeds nitrate level due to greater anaerobiosis and reduction of nitrates migrating with subsurface and intrasol flow into depressions.
Greater mobile phosphorus and potassium content was also discovered in depressions (fig. 8).

This regularity allows the use of the results of topographic survey for preliminary revealing of fertility contours as elementary plots for soil sampling and agrochemical analyzing for the purpose of decreasing agrochemical soil analyzing costs compared to traditional grid sampling.

The sixth regularity of spatial heterogeneity of soil fertility represents noncoincidence of boundaries of various agrochemicals contours among themselves. The regularity was confirmed by the result: the coefficients of correlation between various agrochemical indices of intrafield contours were insignificant (tab. 2).

Although there are similar tendencies of the spatial distribution of soil agrochemical characteristics between its separate parts in the limits of a field due peculiarity of the landscape corresponding to the sixth regularity nevertheless considerable differences of fertility of different intrafield parts are obvious. Therefore for each within-field territorial contour different rates and ratios of nutrients in fertilizer corresponding to the

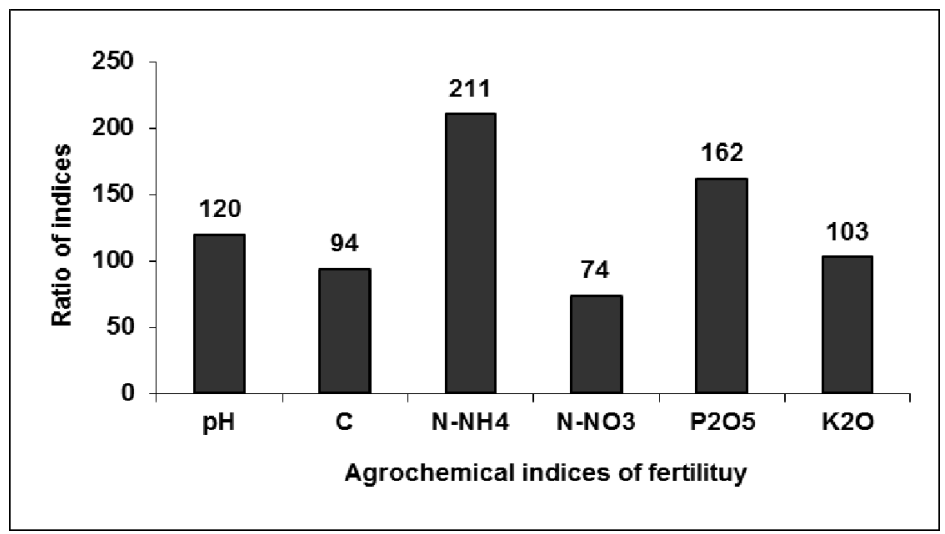

Fig. 8. Ratio of soil agrochemical indices of depressions of the test site vice versa elevations 
Coefficients of correlation of soil agrochemical indices at the agricultural test site

\begin{tabular}{|l|c|c|c|c|c|}
\hline \multirow{2}{*}{ Index } & \multirow{2}{*}{ Humus, \% } & \multirow{2}{*}{$\mathrm{pH}$} & \multicolumn{2}{|c|}{$\mathrm{P}_{2} \mathrm{O}_{5}$} & $\mathrm{~K}_{2} \mathrm{O}$ \\
\cline { 4 - 6 } & & & $\mathrm{mg} / \mathrm{kg}$ & $\mathrm{mg} / \mathrm{l}$ & $\mathrm{mg} / \mathrm{kg}$ \\
\hline $\mathrm{pH}$ & 0.17 & & & & \\
\hline $\mathrm{P}_{2} \mathrm{O}_{5}, \mathrm{mg} / \mathrm{kg}$ & 0.9 & 0.23 & & & \\
\hline $\mathrm{P}_{2} \mathrm{O}_{5}, \mathrm{mg} / \mathrm{l}$ & 0.35 & 0.37 & 0.45 & & \\
\hline $\mathrm{K}_{2} \mathrm{O}, \mathrm{mg} / \mathrm{kg}$ & 0 & 0.12 & 0.48 & 0.46 & \\
\hline $\mathrm{K}_{2} \mathrm{O}, \mathrm{mg} / \mathrm{l}$ & 0.07 & 0 & 0.3 & 0.3 & 0.75 \\
\hline
\end{tabular}

agrochemical characteristics of this contour are necessary. Taking into account this thesis of the technology of variable rate fertilizer application it is required to use machines with simultaneous application of different types of fertilizers or repeated passes of machines adapted for applying one type of fertilizer.

It is necessary to refer greater values of variability of easy-mobile plant nutrients as compared with the values of less mobile nutrients to next (the seventh) regularity. As it is seen in the figure 9; coefficients of variation of easy-mobile $\mathrm{N}, \mathrm{P}$, and $\mathrm{K}$ are half or twice as much again as the values of corresponding mobile nutrients. But for all that crop yield to a greater extent depends on an easy-mobile nutrients (in particular on phosphorus) than on a less mobile nutrients (fig. 10). Taking this regularity into account is very important for increase of agroeconomic efficiency of variable rate fertilizer application because it

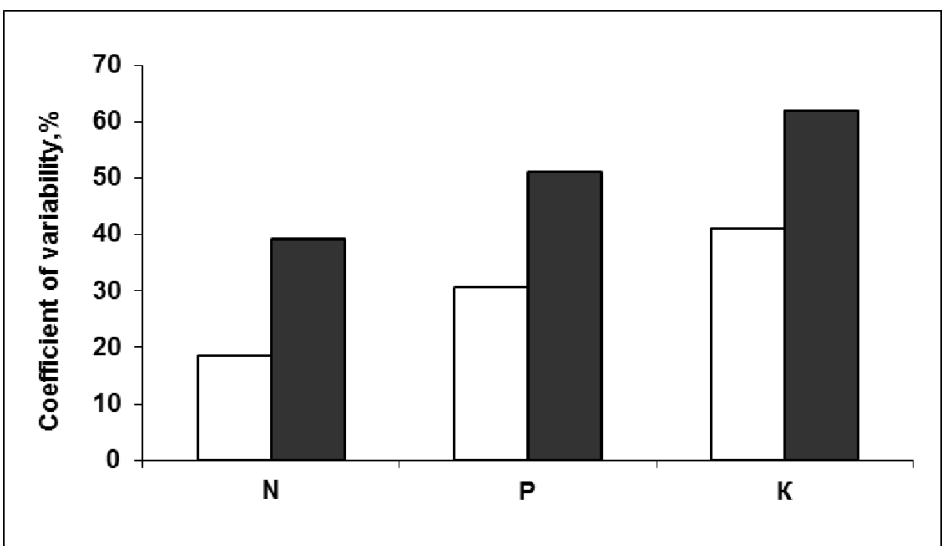

Fig. 9. Variability of mobile (the left row of columns) and easy-mobile (the right row) NPK in soils of the agricultural test site

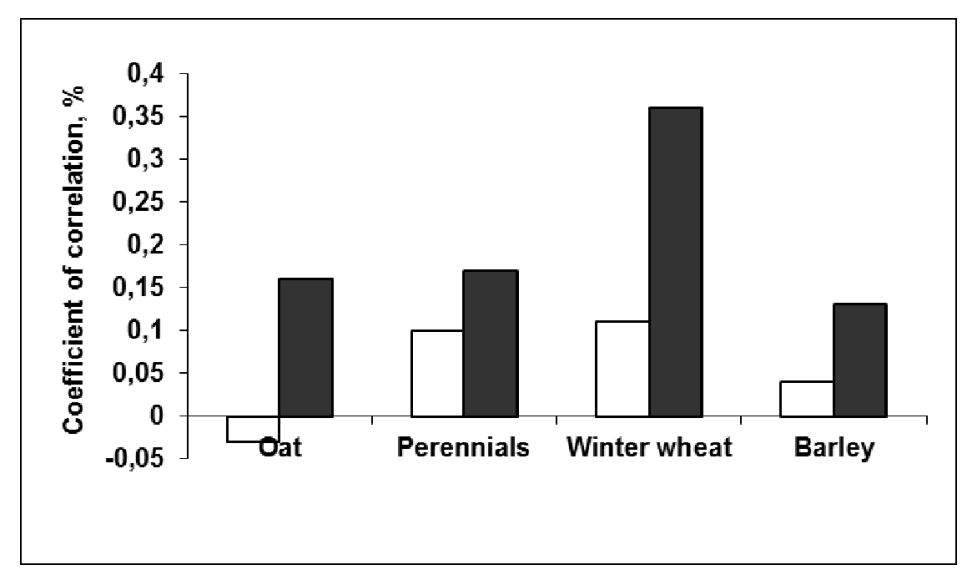

Fig. 10. Influence of mobile (the left row of columns) and easy-mobile (the right row) phosphorus in soils of the agricultural test site on the yield of field crop 
allows more punctually to take into consideration plant-nutrient need. In other words during the agrochemical analysis of soils side by side with traditional indices of its nutrient (mobile N, P, K) supply it is important to determine easy-mobile nutrients and to use these values while calculating the optimal fertilizer rates. This would increase fertilizer application efficiency and avoid losses of the fertilizers.

At the same time one ought to take into consideration the eighth regularity that was revealed by our investigation: although crop yield depends on easy mobile nutrients greater than it depends on less mobile forms this yield varies to a lesser degree than proper mobile forms. In particular as it as seen in the figure 11, the values of coefficients of variation of easy-mobile phosphorus $(V=52 \%)$ and potassium $(V=62 \%)$ in soils of the 400 plots of agricultural test site to a marked degree surpass coefficients of variation of annual grasses hay yield ( $V=41 \%$ ).

With lack of nutrition plants increase root development, they can increase solubility of hard-to-reach soil nutrients, biological activity of soil. The lack of nutrition also activates the functioning of soil microflora. Particularly it is known that activity of soil phosphatase sent off by microorganisms increases when content of mobile soil phosphorus decreases and vice versa $[6 ; 7]$. Many phosphororganic soil substances (phytin, phospholipids, nucleoproteids) are drawn into exchange of microorganisms with subsequent dephosphorylation and transition of phosphorus into soluble compounds. There are microorganisms in soil that capable transform hard-to-reach compounds of potassium whose exometabolites promote the transition of potassium into soil solution [5]. The activity of nitrogen fixers also increases with decrease of easy-mobile nitrogen content in soil. It is important take into account this regularity when estimating the efficiency of variable rate fertilizer application because to a certain degree differences between variants of traditional and differentiated fertilizer application become smooth through ecological flexibility of plants and also the flexibility of soil microflora which responds to dynamics of soil nutrients.

Of course the ability has their limits. For example studies of differentiated application of nitrogen fertilizer in Tyumen region of the Russian Federation where soils were leached Chernozemic, and crops - spring wheat, showed that application of limited rates of nitrogen counting on grain yield $2 t /$ ha variable rate application of nitrogen fertilizer didn't advantage first of all economically as compared with application by averaged rate. The plants at the expense of soil nitrogen equalized to a certain extent the difference in low rates of fertilizers applied in different parts of a field. However with increasing of rates of nitrogen counting on grain yield $3-4 \mathrm{t} / \mathrm{ha}$ difference in nitrogen supply of plants because of its variable rate application resulted in essential economic efficiency [1]. So it is possible to come to a conclusion: if the differences between intrafield agrochemical indices or differentiated fertilizer rates are low one cannot expect essential efficiency of their application because of physiologic flexibility of plants.

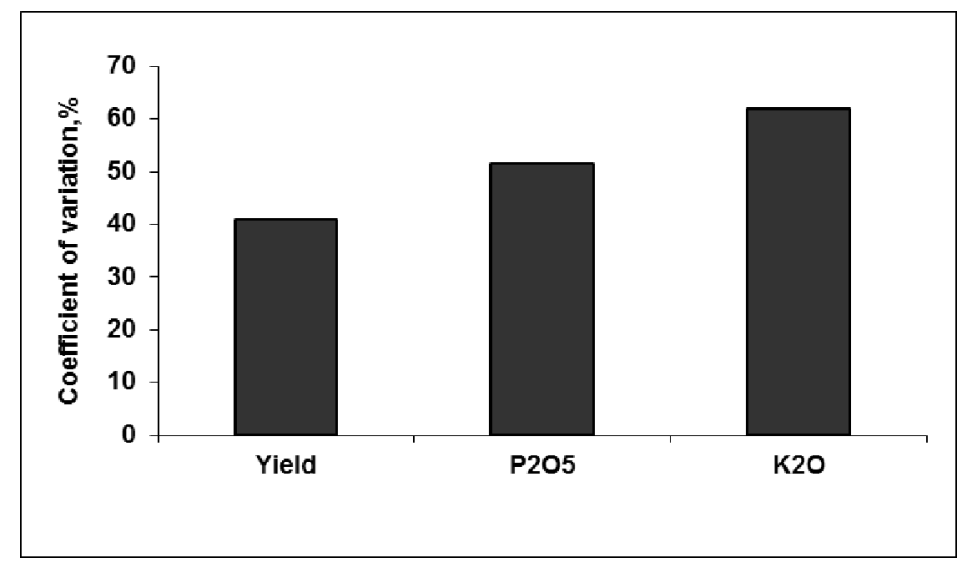

Fig. 11. Variability of annual grasses hay yield and easy-mobile phosphorus and potassium in soils of the agricultural test site 
The regularities of intrafield variability of soil fertility, demonstrated by the example of the testing area of the Central Experiment Station of the Pryanishnikov All-Russian Agrochemistry Research Institute, are characteristic for other types and subtypes of soils where we carried out similar investigations [2]. That indicates their similarity and expedience of utilization when developing high-precision agro technologies of variable rate fertilizer application under different soil-climatic conditions.

\section{Conclusion}

1. The regularities of intrafield variability of agrochemical indices which are general for all zonal soil types and subtypes may become theoretical grounds for more rational use of agrochemicals when developing technologies of variable rate fertilizer application. We found several distinguishing features of intrafield variability of soil fertility, which is necessary to take into account when trying increase efficiency of variable rate fertilizer and amendment application. These features are the dependence of agrochemical properties of soil on the mesoand microtopography of fields, smooth shape of conjugacy of soil contours with maximum and minimum values of agrochemical indices, territorial noncoincidence of contours regarding main agrochemical indices, greater values of variability of easy-mobile plant nutrients as compared with the values of less mobile nutrients, dependence of variability on the area of distinguished intrafield contours.

2. Intensity of intrafield heterogeneity of soil fertility has especial significance for choice of technology of fertilizer application (traditional or differentiated). There are two regularities which cause the intensity: firstly - as a rule the ratio of plots with marginal values of agrochemical characteristics to plots with their average characteristics is low, secondly - soils of marginal plots have the maximum value of agrochemical variability. Basically these regularities of soil intrafield fertility by and large reduce the efficiency of differentiated application of fertilizers.

3. Leveling of the difference in nutrient supply of plants in different parts of a field which is caused to a certain extent by ecologic flexibility of plants also influences on reduction of efficiency and so expediency of differentiation of fertilizer rate. It is necessary to define levels and criteria of soil fertility of agricultural lands for purpose of isolation of areas which are very promising for technologies of differentiated agrochemical application; bearing in mind that the technologies require essential supplemental expenditures as compared with traditional fertilizer application by averaged rate.

\section{REFERENCES}

1. Abramov N.V., Abramov O.N., Semizorov S.A. Cherstobitov S.V. Precision Agriculture as a Part of Resource-Saving Technologies of Crop Cultivation. Geoinformatic Technologies in Agriculture. Proceedings of the International Conference. Orenburg, Publishing Centre of Orenburg State Agrarian University, 2013, pp. 30-40 (in Russian).

2. Afanasyev R.A. Regularities of Intrafield Variability of Soil Fertility Indices. Journal of the Russian Agricultural Sciences, 2012, vol. 38, pp. 36-39.

3. McGuire J. Technology Coordinator Spatial Ag Systems. The Ohio Geospatial Technologies Conference for Agriculture and Natural Resources Applications - March 24-26, 2003. Columbus, Ohio, 2003, pp. 1-42.

4. Merzlaya G.E., Verkhovtseva N.V., Seliverstova O.M., Makshakova O.V., Voloshin S.P. Interconnection of the Microbiological Indices of Derno-Podzolic Soil on Application of Fertilizer Over Long Period of Time. Problems of Agrochemistry and Ecology. 2012, no. 2, pp. 18-25 (in Russian).

5. Rumyantseva I.V., Devyatova T.A., Afanasyev R.A., Merzlaya G.E. Proceedings of Voronezh State University Scientific Session. Voronezh, Voronezh State University, 2011, pp. 45-59 (in Russian).

6. Sokolov A.V., ed. Agrochemical Methods of Soil Investigation. Moscow, Nauka Publ., 1975. 656 p. (in Russian).

7. Sychev V.G., Listova M.P., Derzhavin L.M. Phosphate Regime of Soils for Agricultural Purposes. Bulletin of Geographic Network of Experiments With Fertilizers. Moscow, Pryanishnikov Agrochemistry Research All-Russian Institute, 2011, iss. 11.64 p. (in Russian).

8. Watcins K.B., Lu Yao-chi, Wen-yuan Huang. Economic and Environmental Feasibility of Variable Nitrogen Fertilizer Application With Carry-Over Effects. Journal of Global Positioning System, vol. 23, no. 2, pp. 401-426. 


\title{
ИСПОЛЬЗОВАНИЕ ЗАКОНОМЕРНОСТЕЙ ВНУТРИПОЛЬНОЙ ВАРИАБЕЛЬНОСТИ ПЛОДОРОДИЯ ПАХОТНОЙ ПОЧВЫ В ТЕХНОЛОГИЯХ ТОЧНОГО ЗЕМЛЕДЕЛИЯ
}

\author{
Афанасьев Рафаил Александрович \\ Доктор сельскохозяйственных наук, профессор, \\ Всероссийский научно-исследовательский институт агрохимии им. Д.Н. Прянишникова \\ rafail-afanasev@mail.ru \\ ул. Прянишникова, 31А, 127550 г. Москва, Российская Федерация
}

\begin{abstract}
Аннотация. В статье излагаются закономерности внутрипольного варьирования плодородия почв в интересах дифференцированного применения удобрений в технологиях точного земледелия, в том числе ограничивающие его агроэкономическую эффективность. Как хорошо известно, обычными технологиями применения удобрений предусматривается их внесение по усредненным агрохимическим показателям почвенного плодородия: содержанию в пахотном слое подвижных форм элементов питания растений (азота, фосфора, калия и др.) При этом из-за внутрипольной пестроты плодородия почв часть растений получает избыток, а часть растений - недостаток минерального питания. Это приводит к недобору сельскохозяйственной продукции, ухудшению ее качества, а также к загрязнению внутрипочвенной и окружающей среды излишками агрохимикатов на переудобренных участках полей. В последние десятилетия на смену традиционным технологиям приходят технологии точного земледелия с дифференцированным внесением удобрений с учетом внутрипольной неоднородности плодородия почв. Существует ряд сдерживающих факторов широкого внедрения технологий точного земледелия, к которым относится недостаточный учет характера внутрипольной вариабельности агрохимических свойств почв. Наши исследования выявили восемь закономерностей внутрипочвенного варьирования агрохимических показателей плодородия на пахотных почвах, которые характеризуют почвенное плодородие пахотных почв. Эти закономерности позволят более обоснованно подойти к оценке эффективности дифференцированного применения удобрений в технологиях точного земледелия.
\end{abstract}

Ключевые слова: почва, внутрипольные контуры, вариабельность, закономерности, точное земледелие. 